\title{
Youngsters Perception Toward Social Networking Advertising: Does Social Media Advertising Factors Still Matter?
}

\author{
Dr. Tan Owee Kowang \\ Faculty of Management, Universiti Teknologi Malaysia \\ Nurul Amalina Binti Jonid \\ Faculty of Management, Universiti Teknologi Malaysia
}

Dr. Lim Kim Yew

Faculty of Business and Management, Southern University College, Malaysia

Dr. Goh Chin Fei

Faculty of Management, Universiti Teknologi Malaysia

Dr. Ong Choon Hee

International Business School, Universiti Teknologi Malaysia

Received: April 1, 2018 Accepted: April 23, 2018 Online published: April 27, 2018

doi:10.5296/ijhrs.v8i2.12932 URL: https://doi.org/10.5296/ijhrs.v8i2.12932

\begin{abstract}
Social Networking Sites (SNS) including Facebook, Instagram, Twitter, Linkedin, Flickr and My Space are significantly grown in popularity among youngster and has become powerful media for advertisers as well as advertising industry all around the world. Advertising via social networking platform allows segmentation of advertising activities based on customers' demographic. Hence, it is different from social medial advertising which is public-focused based. Thus, this study aims to explore does the important success factors for social media advertising still matter toward youngsters' perception on social networking advertising. As
\end{abstract}


such, the study assess the relationships between five main social media advertising success factors (informativeness, entertainment, credibility, irritation and customization) with youngsters' perception toward social networking advertising. The study is quantitative based. Data was collected from 274 undergraduate students from the Faculty of Management (FM), Universiti Teknologi Malaysia (UTM) via convenience sampling technique. Data analysis was done via descriptive analysis and Person correlation test. The findings from the study suggested that all the five social media advertising factors are significantly correlated with youngsters' attitude towards social network advertising. In addition, finding from this study also revealed that credibility or the trustworthiness of social network advertising is viewed by youngsters as the least important factor. Perhaps this is because of youngsters generally view information in social network is lack of reliability and credibility as compare with traditional face to face networking platform.

Keywords: youngsters' attitudes, social media advertising, social networking ads, informativeness, entertainment, credibility, irritation, customization personality

\section{Introduction}

Social network advertising is one of the latest forms of online advertising, and is now become part of the vital strategies in any business that aim to attract youngsters' attention or purchase intention (Hart, 2008). Social networking advertising is also known as social media goals or targeting. It is a term used to describe a form of online advertising that focus more on products and services in the social network. Advertising via social networking platform such as Facebook, Instagram, Twitter, Linkedin, Flickr, My Space allows segmentation of advertising activities based on targeted customers' demographic (Lee et. al., 2011). Hence, it is different from social media advertising that focuses on general public as targeted consumers (Kelly et. al., 2010). As such, the question raised is, does the important factors for social media advertising still matter within the context of social networking advertising, particularly for youngster, who made up the major portion of social networking population. Hence, this study aims to address two research objectives. Research objective 1 is to identify the important factors that affecting youngsters' perception towards social networking advertising and research objective 2 is to investigate the relationship between social networking advertising factors and youngster's perception towards social networking advertising.

\section{Theoretical Background}

Consumer perception toward social network advertising is one of the key elements that influence the effectiveness of social network advertising (Tavor, 2011). Whereas, the effectiveness of advertisement, regardless of product or services, could be assessed via the perception level of consumer toward the product or service. Studies done by prior researches (Zabadi and Elsayed, 2012) revealed that from social media advertising perspective, consumer perception is the process of individual exposure toward the advertisement and the level of attention imposed by the consumer toward the product or service. Prior studies also suggested that consumer perception level is significantly related to consumers' buying decision. From literature review, many studies had been conducted by 
prior researchers on the success factors for social media advertising, and the five main factors proposed by prior researcher are summarized in Table 1 .

Table 1. Important Factors for Social Media Advertising

\begin{tabular}{c|c}
\hline Factors & Previous Researcher \\
\hline Informativeness & $\begin{array}{c}\text { Lee et al. (2011), Tavor (2011), Erdem et al. (2006), } \\
\text { Siau et al. (2003) and Zabadi et al. (2012) }\end{array}$ \\
\hline Entertainment & Lee et al. (2005), Lee et al. (2011), Ling et al. (2010) and \\
& Mahmoud (2013) \\
\hline Credibility & Adler et al. (2000), Goldsmith et al. (2000), (Lee et al., \\
& 2011), and Lafferty et al. (1999) \\
\hline Irritation & $\begin{array}{c}\text { Eighmey et al. (1998), Ducoffe (1996), (Lee et al., 2011), } \\
\text { (Yaakop et al., 2013) and Michael et al. (2006) }\end{array}$ \\
\hline Customization & De Zoysa (2002), Rao et al. (2003) and (Liu et al. 2012) \\
\hline
\end{tabular}

\subsection{Informativeness}

According to Lee et al. (2011), informativeness reflected the ability of advertiser to provide adequate and important information in the advertisement in regard with the product and the information is relevant to the targeted consumers. In addition, study done by Tavor (2011) revealed that advertising plays an important role in the product line to deliver comprehensive information to the targeted consumers. Moreover, within the context of social network advertising, consumer might incline to gain more information through interpersonal information exchange in order to gather more information about the product or service (Zabadi and Elsayed, 2012). Thus, Siau and Shen (2003) suggested that high-quality of information delivered by the advertisers will have a huge impact toward the perception of the consumers

\subsection{Entertainment Element}

According to Lee and Johnson (2005), entertainment element on social network advertising refers to the ability to create excitements and fun to the potential consumers via the content and presentation of social network advertising. Furthermore, Lee and Johnson (2005) stated that entertainment element in advertising is the most powerful element of an advertisement, where it need to match consumer's psychology of joy, excitement, gratification, enthusiasm and emotional feelings. Ling et al. (2010) asserted that consumers are more likely to view or assess ads that contain more entertainment and enjoyment elements.

\subsection{Credibility}

Credibility refers to the central point of the trust in the content of the message (Lee et al., 2011). According to Adler and Rodman (2000), credibility is the trustworthiness of the addresser and perception in the minds of the audience. In addition, Lafferty and Goldsmith (1999) revealed that credibility is an important factor affecting the genesis of attitude and behavior towards advertising. 


\section{Macrothink}

\subsection{Irritation Element}

Irritation element in ads can be defined as any advertisement that evokes the bad feelings toward the viewer or potential consumer, including anger, hatred and errors caused by ads (Lee et al., 2011). According to Eighmey and McCord (1998), irritation can be described as content of ads that is messy and annoying to the browser. In addition, Kelly et al. (2010) mentioned that viewers skip the ads or most likely delete the ads to avoid bad feeling (Yaakop and Hemsley-Brown 2011).

\subsection{Customization}

Customization is the nature of social network that allows viewers or consumers to choose advertising information that they want to obtain (Rao and Minakakis 2003) According to DeZoysa (2002), a personalized advertisement and relevant to the viewers' lifestyle are more acceptable by the viewers. Hence, Rao and Minakakis (2003) mentioned that it is crucial for the advertisers to follow viewer requirement, profiles, and patterns. In other words, viewer is probably paying attention to ads that are suitable for them and ads that considered less suitable can be avoided (Liu, 2003).

\subsection{Research Framework}

This conceptual framework for this study is developed based on the concept that the five main success factors for social media advertising that identified in literature review are significantly related to youngsters perception towards social networking advertising as shown in Figure 1.

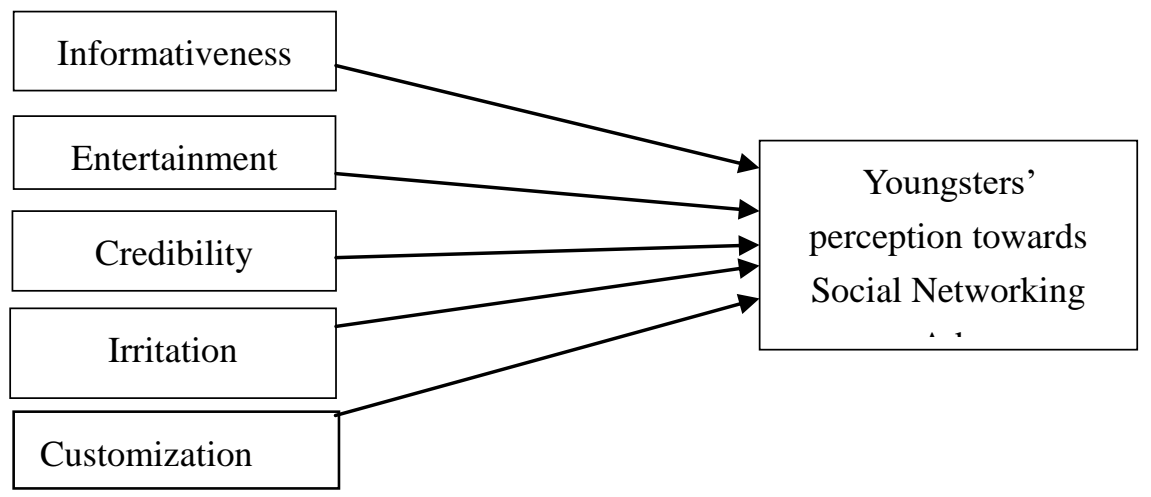

Figure 1. Research Framework

In line with the research framework, 5 research hypotheses are developed as shown Table 2. 
Table 2. Research Hypotheses

\begin{tabular}{c|l}
\hline H1 & $\begin{array}{l}\text { Informativeness is positively related to youngsters' } \\
\text { perception toward social networking ads. }\end{array}$ \\
\hline $\mathbf{H 2}$ & $\begin{array}{l}\text { Entertainment is positively related to youngsters' perception } \\
\text { toward social networking ads. }\end{array}$ \\
\hline $\mathbf{H 3}$ & $\begin{array}{l}\text { Credibility is positively related to youngsters' perception } \\
\text { toward social networking ads. }\end{array}$ \\
\hline $\mathbf{H 4}$ & $\begin{array}{l}\text { Irritation is negatively related to youngsters' perception } \\
\text { toward social networking ads. }\end{array}$ \\
\hline $\mathbf{H 5}$ & $\begin{array}{l}\text { Customization is positively related to youngsters' perception } \\
\text { toward social networking ads. }\end{array}$ \\
\hline
\end{tabular}

Source: Compiled by Author

\section{Method}

\subsection{Population and Sample}

The population of this study is undergraduate students of Faculty of Management (FM), Universiti Teknologi Malaysia (UTM), Skudai Johor. There are five academic programs at Bachelor's levels which are Bachelor of Management (Technology), Bachelor of Management (Marketing), Bachelor of Science (Human Resource Development), Bachelor of Psychology with Human Resource Development and Bachelor of Accounting. The total number of undergraduate students in the faculty is 957. 274 students were selected as sampling size based on Krejcie \& Morgan (1970) sampling table.

\subsection{Data Collection Method}

The study is quantitative based. Survey questionnaire were distributed to 274 students base on convenience sampling. The questionnaire consists of 25 questions which are divided into three sections. First section is to collect respondents' demographic information, while the second and third sections are to assess respondents' perception toward social networking advertising and the important level of social media advertising factors via 5-point Likert Scales.

\subsection{Data Analysis}

Few analysis steps involved in data analysis, which including data normality and reliability test; description analysis to address research objective 1, and Person correlation analysis for research objective 2. All analysis was done via Statistical Package Software Science (SPSS) version 22.0 .

\section{Results}

\subsection{Normality Test and Reliability Test}

Normality test in term of Skewness and Kurtosis are conducted on all dependent and independent variable. Skewness and Kurtosis for all variable are within the range of -1.0 to 
+1.0 suggested that data collected for all variables are normally distributed (Hair, 1998). A reliability coefficient (Cronbach Alpha) of minimum 0.70 is used as the acceptance level for statistical reliability (Hair, 1998). Cronbach Alpha for all variables are analysed and the result shown reliability coefficient for all variable are above 0.70 . Hence, data collected is statistically significant and can be proceed for further analysis.

\subsection{Findings of This Study}

4.2.1 RO1: To Identify the Important Factors that Affecting Youngsters' Perception towards Social Networking Advertising

The mean score for each independent variable is analysed via SPSS descriptive analysis to address RO1, and the result of analysis is shown in Table 2.

Table 2. Summary of Descriptive Analysis

\begin{tabular}{c|c|c|c}
\hline No & $\begin{array}{c}\text { Success factors for Social Network } \\
\text { Advertising }\end{array}$ & Mean & Level \\
\hline 1 & Informativeness & 3.79 & High (Important) \\
\hline 2 & Irritation & 3.46 & High (Important) \\
\hline 3 & Entertainment & 3.37 & High (Important) \\
\hline 4 & Customization & 3.37 & High (Important) \\
\hline 5 & Credibility & 3.19 & Moderate (Neutral) \\
\hline
\end{tabular}

Source: Compiled by author

As refer to Table 2, social media advertising success factors informativeness, irritation, entertainment and customization are also perceived by youngsters as important for social network advertising with informativeness scored the highest mean of 3.79. The finding is in parallel with study done by Nelson et. al. (2006) that suggested informativeness of advertisement is the root of consumer belief that hidden its implicit of economic benefits. However, social media advertising success factor "credibility", which refer to the trustworthiness of the advertiser and perception in the minds of the consumer is ranked as the least important with mean score of 3.19. Perhaps this is because of youngsters generally view information in social network is lack of reliability and credibility as compare with traditional face to face networking platform.

4.2.2 RO2: To Investigate the Relationship between Social Networking Advertising Factors and Youngster'S Perception towards Social Networking Advertising

Data collected is analysed using Pearson Correlation to assess the relationship between social networking advertising factors and youngster's perception towards social networking advertising. Result of Pearson correlation test is summarized in Table 3.0. 
Table 3. Person Correlation Analysis

\begin{tabular}{l|c|c|c}
\hline \multicolumn{1}{c|}{ Research Hypothesis } & $\begin{array}{c}\text { Correlation } \\
(\mathbf{r})\end{array}$ & Significant & Results \\
\hline $\begin{array}{l}\text { H: Informativeness is positively } \\
\text { related to youngsters' perception } \\
\text { toward social networking ads. }\end{array}$ & .682 & .000 & Supported \\
\hline $\begin{array}{l}\text { H2: Entertainment is positively } \\
\text { related to youngsters' perception } \\
\text { toward social networking ads. }\end{array}$ & .675 & .000 & Supported \\
\hline $\begin{array}{l}\text { H5: Customization is positively } \\
\text { related to youngsters' perception } \\
\text { toward social networking ads. }\end{array}$ & .606 & .000 & Supported \\
\hline $\begin{array}{l}\text { H3: Credibility is positively } \\
\text { related to youngsters' perception } \\
\text { toward social networking ads. }\end{array}$ & .604 & .000 & Supported \\
\hline $\begin{array}{l}\text { H4: Irritation is negatively related } \\
\text { to youngsters' perception toward } \\
\text { social networking ads. }\end{array}$ & -.440 & .000 & Supported \\
\hline
\end{tabular}

Source: Compiled by author

As refer to Table 3.0, all the five social networking advertising factors are significantly correlated with youngster's perception toward social networking advertising at significance level of 0.05. In addition, four out of the five social media advertising factors (i.e. Informativeness, Entertainment, Customization and Credibility) are positively correlated with youngster's perception, while factor "Irritation" is negatively correlated with youngster's perception toward social networking advertising.

Finding from this study suggested the coefficient of correlation between informativeness and youngster's perception is the highest with correlation coefficient of 0.682 , followed by entertainment with correlation coefficient of 0.675 . This finding is in line with the study conducted by Siau and Shen, (2003) which revealed that advertisers have to deliver high-quality of information in order to create a positive impact on the perception of customers toward the product or service. The finding from Pearson correlation is also in parallel with study conducted by Dao et al. (2014), which suggested that advertisement with richer entertainment content tends to possess higher positive impact toward customers' perception on social network advertising. In addition, finding from this research also echoes Kumar et.al (2016)'s study which suggested that a valuable, timely and meaningful information concerning a product through social networking advertisement will increase the advertisement value as well as customer purchase intention (Kumar et al., 2016).

\section{Conclusion and Recommendation}

In summary, finding from this research suggested that, within the scope of population under study (i.e. undergraduate youngsters in the Faculty of Management), four out of the five social media success factors, Informativeness, Irritation, Entertainment and Customization are regarded as important factors for youngster perception toward social networking advertising. However, youngster general view social network advertising as platform that lack of credibility and reliability as compare with traditional face to face networking 
platform.

In addition, finding from this research also revealed that informativeness and entertainment are positive and significantly correlated with youngster perception toward social networking advertising. The implication of this finding is, within the scope of population under study, the essential components of a successful and effective social network advertising are dependent on the ability of advertiser to provide adequate and important information in the advertisement in regard with the product and the information is relevant to the targeted consumers, and ability to create excitements and fun to the potential consumers via the content and presentation of social network advertising.

\section{Acknowledgement}

Authors wish to acknowledge the Malaysian Ministry of Higher Education and Universiti Teknologi Malaysia under the Research Grant (Vote No. 4F842) for sponsoring this publication.

\section{References}

Adler, R. B., \& Rodman, G. (2000) Understanding Human Communication, ( th $^{\text {ed.). New }}$ York: Oxford University Press.

DeZoysa, S. (2002). Mobile Advertising Needs to Get Personal. Telecommunications-International Edition. 30(2).

Eighmey, J., \& McCord, L. (1998). Adding Value in the Information Age: Uses and Gratifications of Sites on the World Wide Web. Journal of Business Research, 41, 187-194. https://doi.org/10.1016/S0148-2963(97)00061-1

Erdem, T., Swait, J., \& Louviere, J. (2002). The impact of brand credibility on consumer price sensitivity. International Journal of Research in Marketing, 19(1), 1-19. https://doi.org/10.1016/S0167-8116(01)00048-9

Hair, J. F., Rolph, E. A., Ronald, L. T., \& William, C. B. (1998). Multivariate Data Analysis. New York: Prentice Hall.

Hart, M. (2008) Do online buying behaviour and attitudes to web personalization vary by age group?', Proceedings of the 2008 annual research conference of the South African Institute of Computer Scientists and Information Technologists on IT Research in Developing Countries: Riding the Awave of Technology, Wilderness, South Africa, 1456670: ACM, .86-93. https://doi.org/10.1145/1456659.1456670

Kelly, L., Kerr, G., \& Drennan, J. (2010). Avoidance of Advertising in Social Networking Sites: The Teenage Perspective. Journal of Interactive Advertising, 10, 16-27. https://doi.org/10.1080/15252019.2010.10722167

Krejie, R. V., \& Morgan, D. W. (1970). Determining Sample Size for Research Activities. Educational and Psychological Measurement, 30, 607-610. https://doi.org/10.1177/001316447003000308 


\section{Macrothink}

International Journal of Human Resource Studies

ISSN 2162-3058 2018, Vol. 8, No. 2

Lafferty, B., \& Goldsmith, R. E. (1999). Corporate Credibility's Role in Consumer Attitude and Purchase Intention when a High versus a Low Credibility Endorser is Used in the Ad. Journal of Business Research, 44, 109-116. https://doi.org/10.1016/S0148-2963(98)00002-2

Lee, C. C., Hsieh, M. C., \& Huang, H. C. (2011). The Influence of Mobile Self-efficacy on Attitude towards Mobile Advertising. Advance in Information Sciences and Service Sciences, 3, 100-108. https://doi.org/10.4156/aiss.vol3.issue3.13

Lee, M., \& Johnson, C. (2005). Principles of Advertising: A Global Perspective. United States of America: The Haworth Press Inc.

Ling, K. C., Piew, T. H., \& Chai, L. T. (2010). The Determinants of Consumers' Attitude towards Advertising. Canadian Social Science. 6(4), 114-126.

Liu, Y. (2003). Developing a scale to measure the interactivity of web sites. Journal of Advertising Research, 43(2), 207 - 216. https://doi.org/10.2501/JAR-43-2-207-216

Rao, B., \& Minakakis, L. (2003). Evolution of Mobile Location-Based Services, Communications of the ACM, 46(12), 61-65. https://doi.org/10.1145/953460.953490

Siau, K., \& Shen, Z. (2003). Building Customer Trust in Mobile Commerce. Communication of the ACM. 46, 91-94. https://doi.org/10.1145/641205.641211

Tavor. (2011). Online Advertising Development and Their Economic Effectiveness. Australian Journal of Business and Management Research, 1(6), 121-133.

Yaakop, A., \& Hemsley, B. J. (2011). Attitudes towards Advertising: Does Traditional Media still have its Place in the Future? 1st International Conference on Accounting, Business and Economics.

Zabadi, A., \& Elsayed, E. (2012). Consumer attitude towards SMS advertising among Jordanian users. International Journal of Marketing Studies, 4(1), 77-94. https://doi.org/10.5539/ijms.v4n1p77

\section{Copyright Disclaimer}

Copyright for this article is retained by the author(s), with first publication rights granted to the journal.

This is an open-access article distributed under the terms and conditions of the Creative Commons Attribution license (http://creativecommons.org/licenses/by/4.0/). 